\title{
Analysis of Duchamp and Zen Aesthetics
}

\author{
Yanni Wu \\ Xi'an Academy of Fine Arts, The Department of Oil Painting, 710065
}

\author{
Keywords: Modern art; Zen aesthetics; Rebelliousness; Essence
}

\begin{abstract}
As one of the artists who had great influence on the art history of modernism in the 20th century, Duchamp always realizes his personal artistic value through his constant pursuit of self and self-transcendence. He integrates art with his own life, infuses his own thoughts in every piece of work and realizes his own independent will and spirit of freedom. Both the works and the state of creation and life conform to the concepts of "true self", "sameness" and others pursued by Zen Buddhism. This article is divided into four parts to discuss the relationship and commonalities between the two. Part one is a brief account of Duchamp's life and the evolution of his works. The second part briefly describes the basic content and connotation of Zen and put forward the relationship with art. The third part puts forward its commonalities with Duchamp and discussed respectively from Duchamp's works, as well as the state of creation and life in connection with the basic connotation of Zen Buddhism in the second chapter. The forth part summarizes the creation and life style of Duchamp according to the present artistic condition and puts forward the importance of identity of independence, art and life in conclusion.
\end{abstract}

\section{A Brief Account of Duchamp 's Life and Works}

In 1917, an urinal named "Spring" appeared anonymously in the exhibitions of independent artists in the United States and became one of the landmark works in the history of modern art. It is a well-known fact that it was at that time that the author of this work, which is not unfamiliar to the history of art, solemnly proclaimed to the world his complete rebellion against traditional arts.

As a pioneer of experimental art in the twentieth century, Marcel Duchamp had an important influence on Western art around World War II. The artist who took a pivotal position in the history of modern art was born in France in 1887 and he is one of the representatives and founders of Dadaism and Surrealism. Almost never stopped in a fixed pattern and style in his art creation process and never clinging to a popular genre or group, even though he was referred to as Dadaism. However, in Duchamp's eyes, Dadaism was only one movement, like all other modern schools that demonstrate anti-Semitism, and Dadaism continued to circulate from destruction to defending and re-destruction. Obviously, it is a keen and rebellious nature and a firm pursuit of independence and will create such a man of his own.

Most of Duchamp's early works were in the form of frame painting. At that time, Europe was in the period of economic prosperity. In the era when the old art system was unable to meet the artist's free will, Duchamp accepted various genres such as Post-Impressionism, Fauvism, Cubism and Futurism. Around 1912, his works were frequently exhibited in the Cubist exhibition and the famous "Nude Downstairs" was born during that period. It was only when the painting was dismissed on the so-called "style" controversy at the 1913 Salon that he realized that the art groups that flaunts a "doctrine" and "spirit" were a limitation for him. It was also from that time that Duchamp's creative approach gradually shifted from frame painting to ready-made creation.

The bold challenge to traditional aesthetics is fully reflected in Duchamp's ready-made works of art. He draws creative inspiration from various industrial products and daily necessities produced by human society, simplifies the processing of the objects and gives them personal feelings, which makes the objects have a new meaning different from the original ones. In 1913, he did the "Termination of Three Standards", which showed a mockery of scientific metrics. In the same year, he also made a sculpture with a bicycle wheel fixed on the stool, which is the beginning of the ready-made products. In 1914, the concept of "Big Glass" began to be conceived. In the following years, the famous "Spring", "Unfortunate Ready-made Products" and "Paintings of Bearded Mona 
Lisa" were published. These works occupy a rare position in the art history of the 20th century and broaden the scope of the art forms and themes for contemporary art practitioners. Besides, it also breaks the inherent and rigid aesthetic standards of a long time, blurs the boundaries of art and life and achieves the comforting function of art as a human spirit.

As one of the artists who had a tremendous influence on modern American art after the Second World War, Duchamp created works of art in an unconventional way. Even though there are only a handful of his works, each one is full of profound doubts and denials, impinging upon the inherent limitations of his own and history in a contradictory, relative and rebellious spirit.

\section{The Thought and Art of Zen}

If Nietzsche's "Will to Power" can be used to explain Dusan's rebellion, to interpret his works as "unconscious" with Freud's psychology and to explain his special identity with Kandinsky's "spiritual triangle" theory, then the Zen idea may equally apply to explaining the artist's and his work's spiritual inner.

The Basic Connotation of Zen Thought. Zen is a large sect of Chinese Buddhism founded on the Bodhi Dharma monk. On the basis of the Buddha Sakyamuni that "Everyone can become a Buddha," he further proposed that "Everyone has the nature of Buddhism and he can be rewarded through his practice." In his doctrine of "two-entry", Bhutan said that he is deeply convinced that all living beings are one and the same as one's true nature. Therefore, it makes one be reckless and fix one's mind as a firm belief. This is the basic theoretical foundation of Zen.

In short, Zen Buddhism upholds the values of freedom and liberation, that is, everyone can become a Buddha. And a person's life is a process of self-awareness, self-purification and self-improvement, which is the most spiritual emancipation and liberation.

Zen Buddhism in all sects of the longest spread in China's philosophy also has an important influence. From the Song and Ming dynasties to the modern bourgeois ideas, philosophers all got their nourishment from that. However, the so-called Zen does not refer to a specific method of practice, but refers to a state of comprehending nature. It is an epiphany when accumulated for a long time and is not bound by knowledge.

The Relationship between Thought and Art of Zen. Disregarding the dualism theory of Eastern and Western art, the commonalities between human civilization and wisdom are nothing more than releasing new experiences in the process of breaking away from the ego and continuously pursuing spiritual emancipation. On the artistic method, western painting has gone through a gradual reflection from the partial reflection on the appearance to the inner one. The boundary of art and life is gradually vague from art above life and the form takes the domination position from the dependence on literature and history. In the Chinese concept of art, the superb technique of the artist is always small compared with that of the natural world. Zen's thought requires that the spiritual awareness of painters, sculptors and calligraphers become the intrinsic force of the works, and the intrinsic force goes far beyond nature. This is also an important concept support for the existence of literati painting. Zen respects the universal values of equality of beings and seeks to find deeper and closer human beings behind morality and order, such as the people-oriented and human liberation advocated in Western Renaissance and Enlightenment. From this point of view, the goal of common pursuit of instinct and essence has become the key bridge that takes the philosophy of the East and the West as well as the bridge between the Zen Buddhism and the arts.

\section{Common Features of Duchamp 's Artistic Thought and Zen Thought}

The notion of "Jian Xing Cheng Fo" has greatly expanded the field of Buddhism. Just as the idea of "living everywhere is art", it is precisely the important idea of expanding the scope of art form. The 20th century art development is the most powerful proof of the times that the boundary between "life and art" and "artist and non-artist" has become vague, and Duchamp living in this era has done real freedom and liberation at this level. 
According to the basic connotation of Zen Buddhism in the previous chapter, Duchamp's life is almost always in the process of constant pursuit of self and surpassing of self. He believes that art is the expression of thoughts and emotions, turns against order and reason and pays attention to human instinct as the essence of his thought. In the early 20th century, Duchamp boldly broke the limits of traditional art and aesthetic standards and began to diversify its art forms. Just as Zen gave up the thinking of words and languages, abandoned simple logical speculation, and at the same time gave up the skills, techniques and rules, instead revealing the true psychological and physiological laws of human nature.

The free will of Zen and "true self" are vividly demonstrated here by Duchamp. The following will discuss from two perspectives, that is, his works and creative status and life.

From the Perspective of the Work. Suppose Duchamp has always adhered to the Cubist style of creation, perhaps his artistic life will be a steady and equally successful process. But if so, is not his life too boring?

Therefore, after the rejection of "Nude Downstairs", Duchamp mostly adopted the method of creating finished goods. His ready-made not only broke the traditional art evaluation criteria, but he saw the limitations of art is not art itself, but its own limitations. In those days when all kinds of "doctrine" prevailed, artists were busy creating new genres and theories, but these genres did not always deviate from the forms of painting and sculpture. In Duchamp's view, people are essentially unjustly destroying the essence of things because of the differences between right and wrong, logic, and definitions due to different concepts and comparative methods.

"Spring" created in 1917 and "Paintings of Bearded Mona Lisa" created in 1919 are two of his most famous works of ready-made creation. At the same time, it is also his strongest irony of traditional art and aesthetics. Simple processing of existing items or artwork leads to extraordinary results, which is an easy ridicule of the solemn title of "master", a powerful challenge to classical aesthetics, and the most direct proposal of the question "what exactly is art?".

Big Glass (Figure 1) (also known as "Even the bride was stripped of clothes by bachelor hanks") was done by Duchamp for eight years. This work fully embodies his desire to "get rid of the inherent painting habit" by choosing glass as the carrier and using mechanical drawing to depict the figure as his endeavor to explore new forms.

Another representative work, "Broke Your Arm" (Figure 2), is an epoch-making work by Duchamp. He sent the snow shovels bought from the store directly to the gallery as an exhibit, but wrote the words "before his arm breaks" on the snow shovel when asked to "make sense." However, it still does not have any meaning for him. In contrast, Duchamp seems to have realized earlier than poor artists in Italy on how to relinquish the desire for over-interpretation and return the most essential physicality of things. And this is exactly the essence of Zen Buddhism tries to pursue.

The insurrection to the inherent standard, the continual surpassing of oneself, the free and easy use of the form and the pursuit of the nature and the "true self" are all strongly prosecuted in Duchamp's works and are also the strong arguments of the Zen spirit.
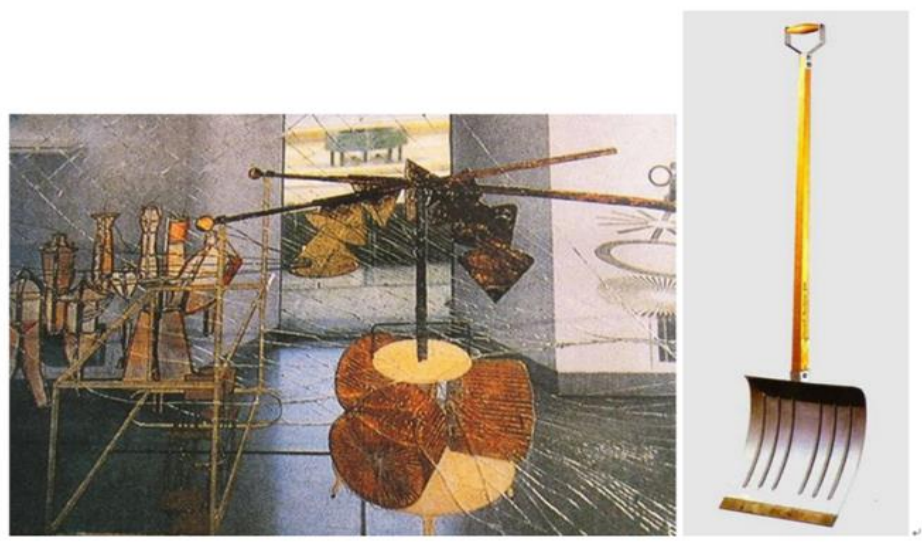

Figure 1. Big Glass

Figure 2. Broke Your Arm 
From the Perspective of Creative State and Life . Zen emphasis on "self-nature and not from outside", literally can be learned that it is emphasis on starting from their own hearts and get out of the affect from the environment. Everyone in a complicated interpersonal relationship may be aware that it is not easy for them to get rid of the influence from others and the environment, which requires a strong personal and independent will.

However, few artists, like Duchamp, have maintained their clear-cut minds under the prevailing circumstances of various neo-schools and new theories and insisted on their own unique creative journey. He is non-utilitarian, does not build factionalism and regards art as part of his life. Besides, his complete denial and suspicion is precisely to show a strong free will.

Duchamp, with his unhindered attitude to life, made an unprecedented change in his personal artistic process and the current state of art. His attitude to life just as Zen advocated - to abandon the role of the human mind, grasping life at a totally unobtrusive level and life can be completely free at this level, which makes life become art.

\section{Duchamp Spirit and the Present Art Form}

Throughout the development of art, in the philosophy of Zen, the unity of art and life is a life of Zen, which is a very natural phenomenon. It is more real, more consistent and inclusive in a real world, without resorting to it for some purpose. In Duchamp's life, art has long been a part of himself and an indispensable spiritual pursuit. Similarly, there is no shortage of artists who are sober-minded, such as Picasso, Marx Beckman, Lüpeel Ci, and other famous artists of different ages. Of course, there are a lot of people who regard art as a kind of utilitarian means. Unfortunately, they make up the majority.

After experiencing a great variety of "movements" and developments in contemporary art, the innovation of forms have almost reached the end and the painting on the shelves faces even greater threats and challenges. Under the impact of the media and the Internet, the enormous amount of information makes it harder for artists to master their own independent intellectual sovereignty. Because of this, it is even more important to uphold individualism and integrate art with life.

Because Zen denied the role of reason to some extent, life is seen as a whole and a purely natural product. In addition to embodying the origin and spontaneity of life, all the activities of Duchamp broke any stereotypes and inherent habits. With his sincere attitude, he implemented artistic creation and activities and truly realized the unity of art and life.

\section{Reference}

[1] "Spirit in Art", [Russian] Kandinsky, Z. W. Li and Others Translate. Renmin University of China Press, 2003.

[2] "Art History of the 20th Century", [Germany] Uwe Schneider, J. H. Shao and Others Translate. China Federation of Literature Press, 2014.

[3] "History of Western Art", X. L. Ma. Hebei Fine Arts Press, 2009.

[4] "The Logic of Feeling", [France] Jill Deleuze and Q. Dong. Guangxi Normal University Press, 2007.

[5] "Art and Vision Consciousness", [US] Rudolf Arnheim and S. Y. Teng. Sichuan People's Press, 2006.

[6] "Duchamp's Art", Q. Lin. People's Press, 2012.

[7] "Interview with Duchamp", (France) Pierre Cabana and R. Y. Wang. Guangxi Normal University Press, 2013.

[8] "History of the Development of Chinese Zen Thought", T. X. Ma. Wuhan University Press, 2007.

[9] "Zen and Taoism", H. J. Nan. Fudan University Press, 2016.

[10]"Picasso and Duchamp", (United States) Larry Witham and Q. Tang. Renmin University of China Press, 2014. 